\title{
Pääkirjoitus
}

\section{Hyppy yli siilojen}

Työpaikallani on vietetty syksyn aikana monia läksiäisiä ja lisää on tulossa talven aikana. Kollegat siirtyvät eläkkeelle ja toisiin työpaikkoihin. Myös uusia työntekiiöitä tulee, vaikkakin vähemmän kuin lähtee. Nykyisin on harvinaista, että lähtevä työntekijä voi olla uuden kanssa samaan aikaan töissä ja perehdyttää hänet työhön.

Kollegoita hyvästellessä tulee usein mieleen se osaaminen ja tieto, joka toisen mukana poistuu. Osa siitä on olennaista organisaation kannalta, mutta ei välttämättä kaikki. Kuten Helsingin yliopiston kirjaston ikätasa-arvoselvitykseen vastanneet työntekijät totesivat: kaikkea työuran aikana kertynyttä hiljaista tietoa ei ole syytä siirtää, sillä osa siitä voi liittyä toimintatapoihin ja käytäntöihin, jotka eivät enää ole ajankohtaisia eivätkä tarpeellisia (Järviö 2010, 24).

Isossa organisaatiossa työskennellessä tuntuu joskus myös siltä, ettei aina pysy perässä siinä mitä kollegat tekevät, mitä heidän projekteissaan ja työtehtävissään tapahtuu. Monet meistä käyvät esittelemässä työtämme ja hankkeitamme kansallisissa ja kansainvälisissä konferensseissa, mutta ihan jokaiselle kollegalle omasta työstä ei ehdi eikä muista kertoa.

Helsingin yliopiston kirjastossa osaamisen kehittämisen ja asiakaspalvelun parissa työskentelevä tietoasiantuntija Anne Kakkonen havahtui tähän ongelmaan ja alkoi miettiä ratkaisua. Syntyi ajatus yhdessä työhyvinvointiryhmän kanssa järjestettävästä kirjaston omasta konferenssista, jossa kollegat kertoisivat työstään ja samalla tutustuttaisiin konferenssikäytäntöihin.

Niinpä kesäkuussa 2017 kirjaston henkilökunta kokoontui Katajanokalla ja esitti toisilleen esitelmiä, joita oli aiemmin esitetty ympäri maailmaa. Tilaisuus sisälsi myös posterisession, jossa posterit esiteltiin ja muut saivat kysyä aiheesta. Illalla pidettiin iltajuhla, kuten kunnon konferenssiin kuuluu.

Päivä kokonaisuutena sai paljon positiivista palautetta. Kommenttien perusteella yhteiset tilaisuudet ovat todella tarpeellisia isossa, neljälle kampukselle ja kolmeen palvelukokonaisuuteen jakautuneessa organisaatiossa, sekä osaamisen että yhteisöllisyyden kehittämisen näkökulmasta. Palautteessa kiitettiin sitä, että runsas määrä lyhyitä 15 minuutin esityksiä antoi hyvän kokonaiskuvan kirjaston toiminnasta, mut- 
ta toisaalta moni löysi esityksistä uusia, mielenkiintoisia aiheita, joista olisi halunnut kuulla enemmänkin. Tähän tarpeeseen on pyritty vastaamaan joka kuukausi järjestettävässä henkilöstöinfossa, ja myös konferenssille on luvassa jatkoa jossain muodossa jo tulevana vuonna. Lue lisää tilaisuuden herättämiä ajatuksia tästä lehdestä, Eeva-Liisa Viitalan kirjoituksesta "Aika hengittää".

\section{Lähteet:}

Helsingin yliopiston kirjaston tietoasiantuntija Anne Kakkosen haastattelu 7.12.2017.

Järviö, Nina, 2010: Toisilta oppimista ja arjen haasteita. Henkilöstön kokemuksia ikätasa-arvon toteutumisesta Helsingin yliopiston kirjastossa. Helsinki: Helsingin yliopiston kirjasto. http://www.helsinki.fi/kirjasto/files/2313/5209/4645/ HULib_ikatasa_arvoraportti2010.pdf (Luettu 5.12.2017)

Johanna Lahikainen 